\title{
診療ガイドラインレビュー \\ 1. Disseminated intravascular coagulation (DIC)
}

松田保

Key words: FDP, 血小板, ヘパリン

はじめに

DIC (disseminated intravascular coagulation) は 1993 年の内科学用語集では播種性血管内凝固 の訳名があてられているが, DICの略名が最も一 般的である. DICは一種の症候群であり,臨床的 には最も極端な血栓傾向であるにもかかわらず, 血管内に扔ける汎発性のフィブリン形成の結果, 血中の血小板数やさまざまの凝固因子（ことに フィブリノゲン) 濃度が消費によって低下する こと，つまり消費性凝固障害による出血性素因 をしばしば伴うこと”から,当初珍しいと考えら れた. しかし，その後，必ずしも当初考えられ ていたほど珍しくないことが明らかとなり，厚 生省（現厚生労働省）もこれに注目して，その 早期診断, 治療を目指す研究班を組織したこと がある.このことは, 現在DICに関するわが国の 診療のレベルが高いこと（このことは海外でも 認められており, 著者は日本のDICの診療と海外 のそれとの間には約 5 年の差があると考えてい

まつだ たもつ：金沢大学名誉教授
る)の原因の一つとなっている. 本稿では, DIC の診断, 治療についての内外のガイドラインを レビューする.

\section{DICの定義}

後に述べるように, DICの診断の内外のガイド ラインは数多く, 多少の混乱が見られるが, そ の理由は肝腎のDICそのものの定義が,ガイドラ インを決める学者によって多少異なることにも よる.日本ではいわゆる厚生省の診断基準2が広 く用いられているが,それは検查上DICであるこ とが明らかであるのに，それに気付かない医師 たちに対する啓蒙の意味もあったのであって， 血液内科において，厚生省の診断基準を満たす までDICの治療を開始しない医師はむしろ少数派 に属する.このことはDICの診断を早期に行なっ て治療を開始したいと言うことが現場の医師た ちによって求められていることを意味するが, 日本の保険診療の場合, DICと診断しない限り DICの治療を行なえないことも,このことと無関 係ではないと思われる.

著者淿はDICを「さまざまの原因によって全身 
の主として細小血管内に沉発性にフィブリンの 形成を生ずること」と定義しているが，「同時に フィブリンを溶解する機序（線溶機序）も活性 化されるので, 生じたフィブリンの大部分は早 急に溶解する」こと，またあまりこれまで強調 されなかったが,「DICにおけるこの血管内での フィブリンの発現は持続的に生ずること（具体 的には 24 時間以上)」が必要と考えている.この 中には，前述の消費性凝固障害の存在を取り上 げていない.つまり血小板数の低下はともかく， 凝固因子漂度の低下を伴わない，つまり定型的 な消資性凝固障害を生じないDICもあり得ると考 えているのである。このことは「生体内」(後述 のように必ずしも「血管内」とは限らない）に 生じたフィブリンの分解産物のルーチン検查に よる测定が可能となるとともに，当初考えられ ていたような定型的な消費性凝固障害を呈する 症例以外も，日本ではDICと考えられるように なったことに基づいている。このように，疾患 や症候群の概念が当初の考え方とは異なってく ることは少なくなく，著者はこれは学問の進歩 と考えている.

しかし，海外に抢いては定型的な消費性凝固 障害を生ずることを重要視していると思われる。 DICに関する最も新しい海外の情報である 2001 年 7 月フランス,パリで行なわれた第 18 回国際 血栓止血学会での標準化委員会 (SSC)における 議論では，Taylorらは，「DICはさまざまな原因 によって引き起こされる広範な血管内の凝固活 性化を特徽とする後天的な症候群であり，微小 血栓は細小血管で生じるとともにこれに障害 を与え，極めて重症になると機能障害を来すこ ともある」と提案していて, 消費性凝固障害に は触れていない.しかし，後に述べるように， 明白な（overt）DICについての実際の診断基準 ではプロトロンビン時間の延長を重視するなど， 消費性凝固障害の存在を重視している。

\section{DICの診断}

一般に，る症候群の診断に必要なのは，そ の症候群を引き起こす疾患, 特有な症状, 検査 所見などであるが, DICの場合には以前より特有 な血液凝固検查所見の異常,ことに血小板,フィ ブリノゲンの低下が注目され，DICの本質をなす 血管内における血栓の多発（血栓の前段階物質 の形成と言う意味なら「凝固活性化」)を示す指 標の検出は，それが困難であったためもあり， 当初は無視された. しかし, 現在はFDP (fibrin) fibrinogen degradation products), SFMC (soluble fibrin monomer complex) やTAT (thrombin-antithrombin complex) など生体内で凝固 活性化を生じたことを示す指標が測定可能とな り,ルーチン検查化されつつあるので, DICの診 断に用いられ, DICの定義そのものを摇るがしつ つあることは前述した。ただし，これらの增加 は，必ずしも血管内での産生の増加ではなく， たとえば筋肉内での産生の増加によることもあ り得る.したがってFDPの増加のみでDIC と診断 することは出来ない.

ただし，FDPはフィブリン及びフィブリノゲ ンのプラスミンによる水溶性（流血中に存在す ると言う意味）分解産物を反映し，もし後者が 主体であるならばその増加は線溶活性化を示し ても生体内でのフィブリン形成の指標とはなら ないが，実際はフィブリンの分解産物が多いの でむしろ凝固活性化のマーカー,つまり血管内 （正しくは前述のように生体内）での凝固を示す と考えられている。

またDダイマーはフィブリンのプラスミンによ る水溶性分解産物のことであり，フィブリノゲ ンの分解産物ではない点,FDPよりDICに特異的 である.わが国ではD-Dダイマーと呼ばれること もある.これはその分子構造中にフィブリノゲ ン分子中に存在するD分画と呼ばれる分子が 2 分 子, ダイマーとして接合された形で含まれるか 
表 1. Colman 5のDIC 診断基準

\begin{tabular}{|c|c|}
\hline \multicolumn{2}{|l|}{ 〈スクリーニング試験〉 } \\
\hline 血小板数 $\leqq 150,000 / \mu 1$ & (正常 $250,000 \pm 50,000 / \mu 1$ ) \\
\hline プロトロンビン時間 $\geqq 15$ 秒 & (正常 $12.0 \pm 1.0$ 秒) \\
\hline フィブリノゲンミ160 mg/d & (正常 $230 \pm 35 \mathrm{mg} / \mathrm{dl}$ ) \\
\hline \multicolumn{2}{|l|}{ 〈線溶の確認試験〉 } \\
\hline FDP $\geqq 1 ： 16$ (正常の2 倍以上) & （正常@1：8） \\
\hline トロンビン時間ミ25 秒 & (正常 $20 \pm 1.6$ 秒) \\
\hline ユーグロブリン溶解時間 120 分 & (正常>120 分) \\
\hline
\end{tabular}

らである.この物質はプラスミンによるフィブ リン分解のさまざまの段階で水溶性となったも の全てを指すのであるが, 通常, 分解が進むほ ど測定值が低下する.つまり分解が進めば分子 数が増えるのであるが,個々のDダイマーの測定 值は著明に低下するので, 全体としては測定值 は低下するのである.ただし，DICの診断に差し 支えるほどではない.しかし，このことや，D ダイマーの測定值自体が標準化されていない(つ まり, 測定方法により著しく測定値が異なる) と 言う久点がある。

SFMCは可溶性フィブリン・モノマーと訳され る.フィブリノゲンがトロンビンの作用を受け たとき，不溶性のフィブリンに転化する前にま ず水溶性のフィブリン・モノマーに転化する. この物質が前述のFDPと水溶性の複合体を形成 したものを指すので, その増加はフィブリンの 形成増加を意味する。

TATはトロンビンとこれを中和するアンチト ロンビン（アンチトロンビンIIとも呼ぶ. 本稿 では国際血栓止血学会の勧告に従いアンチトロ ンビンと呼ぶ）との複合体を意味する。この複 合体はトロンビン自体に比べ血中半減期が長い ため測定が可能で，トロンビンが形成されてい ることの指標となる.

\section{1) Colman $5^{4)}$ の診断基準}

1972 年, マサチューセッツ総合病院のColman らにより発表されたDICの診断基準は最も古い診 断基準である (表 1).この診断基準は 2 段階に
分かれているが, 線溶の活性化の証明がDICの診 断上必須と考えられていたことがうかがえる. なお，現在最も重視されているFDPは当時は線 溶試験と考えられ，まだ一般化していなかった ため，二次的な地位に止まっている点に不満が ある。

また,肝硬変症はフィブリノゲンの産生低下, 血小板数の低下，ときにFDPの増加（食道静脈 瘤中に生じたフィブリンの溶解，肝障害による FDP代謝の低下，また少なくとも一部の例では 潜在的にDICを生じていること）などからDIC との鑑別が困難な疾患の一つであるが, Colman と共同で, Minnaらは肝硬変症を有する例におけ るDICの診断基準を発表している.しかしっこの 診断基準はプロトロンビン時間, 血小板数,フィ ブリノゲンについての基準を蕨しくしたものに 過ぎず,現在の目からはDICの診断基準としては 適当ではない。またこのほか，彼らはへパリン 療法による凝固異常の改善をDICを示すものとし てあげているが,実際問題としてDICの診断が困 難である場合にへパリンを投与してみることは ほとんどないので,この点についても省略する。

\section{2）Al-Mondhiryの診断基準}

Al-Mondhiry ${ }^{5)}$ は 1975 年, 白血病などを含む悪 性腫瘍の例にみられたDICの例を報告したが,そ の際DICと考えた根拠として表 2 のような診断基 準を示した。この診断基準は，あまり有名では ないが,Colmanら"のそれに比し明らかに優れて いて，フィブリノゲンと血小板のほかに, FDP 
表 2. Al-Mondhiry の DIC 診断基準

1.フィブリノゲンの量的变化

(a) フィブリノゲン< $150 \mathrm{mg} / \mathrm{dl}$ か，または

(b) 6 日以内にフィブリノゲンが 50\%以下に低下

2. フィブリノゲンの質的変化

（a）フィブリノゲン量 $>50 \mathrm{mg} / \mathrm{d}$ *で，トロンビン時間が対照に比しその標準偏差の3 倍以上に延長するか，または

(b) FDPが 1:16または $12 \mathrm{mg} / \mathrm{dl}$ 以上に增加

3. 血小板数低下

最近化学療法を行っていないか，または沉骨檤性疾患を有しない例において，血小板数が $10 \times 10^{4} / \mu 1$ 末満

4.第3を満たさぬ思者では，プロトロンビン時間が対照に比しその標準偏差の2 倍以上に延長

上記の基準全てを満たせば DIC

(*原文では第2 項(a)のフィブリノゲン量は $50 \mathrm{mg} / \mathrm{dl}$ と記載されているが, $150 \mathrm{mg} / \mathrm{dl}$ の誤りと思われる)

表 3. 著者の 1976 年の DIC 診断基準

\begin{tabular}{c|rr|lr}
\hline $\begin{array}{c}\text { フィブリノゲン* } \\
(\mathrm{mg} / \mathrm{dl})\end{array}$ & \multicolumn{2}{|c|}{ 血小板数** } \\
$\left(\times 10^{4} / \mu \mathrm{l}\right)$ & FDP $(\mu \mathrm{g} / \mathrm{ml})$ \\
\hline$\leqq 100+3$ & $\leqq 5$ & +2 & $\geqq 40+2$ \\
$\leqq 150+2$ & $\leqq 10+1$ & $\geqq 20+1$ \\
$\leqq 200+1$ & $\leqq 15$ & 0 & $<20$ & 0 \\
$\leqq 250+0$ & $\leqq 20$ & -1 & & \\
$\leqq 400-1$ & $>20-2$ & & \\
$>400-2$ & & &
\end{tabular}

*転移を有する悪性腫瀑・急性白血病增悪期または重 症感染症の存在は+1, フィブリノゲン産生低下(肝実 質障害など)はー1〜ー2

**血小板産生の低下はー1〜ー2

上記の 3 項目の得点が合計 4 点以上はDIC. 3 点では DIC の疑いが濃い，2 点以下でも必す心も DIC の存在 を否定できない，また，悪性腫瘄または急性白血病と 重症感染症が併存しても己点以上は追加しない.

を重視するようになりつつあることを示してい る.またフィブリノゲン量の低下のほかに，そ の低下速度を問題にしている.フィブリノゲン の生体内半隇期が 2 日半であることを考慮すれ ば,フィブリノゲンが急速に低下するのはDIC の結果である可能性が高い，また，悪性腫犜の 例でフィブリノゲンの産生が立進している場合, フィブリノゲンが $150 \mathrm{mg} / \mathrm{dl}$ 未満にならなくても 診断し得るように作られている。 なお，第 4 項 は, 急性白血病のように血小板の低下が疾患そ のものによっても生じ得る場合を考慮している と思われる。

\section{3）著者(6)古いDIC診断基準}

1976 年, 著者はDICについて発表したが, そ の際どのようなものをDICと考えているかを示す ため, 表 3 に示すようなスコアリングによる診 断基準を発表した。この基準は悪性腫瘍（造血 器悪性腫瘍を含む), 感染症, 肝実質障害におけ るフィブリノゲンの産生の充進や低下, さまざ まな原因による血小板産生の低下を考慮してい るが, 現在の目では, FDPの増加をさらに重視 すべきだったと思われる.

\section{4) Siegal ら)のDIC診断基準}

1979 年, SiegalらはDIC診断基準（表 4) を発 表している.彼らもDICの例の集計に際してのも のである. 彼らは新生児の凝固の特殊性を考慮 しているが，FDPはな㧍特殊視されている. 第 5 項のプロタミン試験はSFMC増加を定性的に反 映する測定法である。

\section{5) Spero ら $^{8)}$ のIC診断基準}

1980 年, Speroらは表 5 に示すDICの診断基準 を発表した. 同様にDICの集計に際して,どのよ うな例をDICと考えたかを示す必要があったため である.この診断基準ではFDPの増加またはparacoagulation test (Siegalらのプロタミン試験と同 義)の陽性はDICの診断上必須となっており，さ らに一段と進歩している。な扔, プロトロンビ ン時間は診断基準から除いている，ただし，第 4 項では具体的ではないが, アンチトロンビン濃 度の低下を基準に加えている.DICでは血管内に 
表 4. Siegal 5のDIC 診断基準

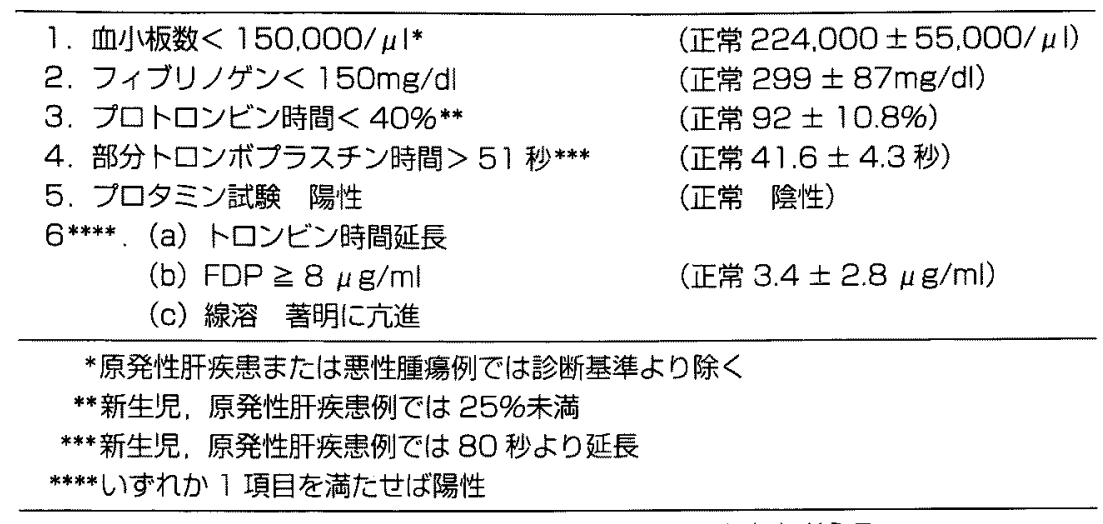

上記の 6 項目中少なくとも 3 項目を満たすとき DIC の存在を考える

\section{表 5. Spero らのDIC 診断基準}

\begin{tabular}{l} 
1. 血小板数低下 $(<150.000 / \mu \mathrm{l})$ \\
2. FDP增加 (>10 $\mu \mathrm{g} / \mathrm{ml})$ \\
3. paracoagulation test 陽性 \\
4. アンチトロンビン罗 低下 \\
5. 未梢血液淦抹標本上破砕赤血球 $(>10 \%)$ \\
6. フィブリノゲン低下 $(<150 \mathrm{mg} / \mathrm{dl})$ \\
\hline
\end{tabular}

以上のうち FDP 增加または paracoagulation test

陽性を含み，少なくとも 3 項目陽性なら DIC.

トロンビンを生じ，これを中和するアンチトロ ンビンが消費されて低下しそうである．実際に DICの例ではほとんど全例, トロンビンとアンチ トロンビンとの複合体であるTATの血中濃度が 増加する。しかし，理由は明らかでないが，急 性前骨髄球性白血病では明らかにDICを生じてい ると思われる例でも，ほとんど血中のアンチト ロンビンは低下しないし，また金沢大学朝倉ら によれば,敗血症に合併するDICの例でも血清蛋 白の低下している例のみで血槳中のアンチトロ ンビン濃度が低下するので, アンチトロンビン の低下はDICに特異的ではないと考えられ,この 点に欠点がある。

6）日本の厚生省研究班によるDIC診断基準

表 6 は 1980 年に群馬大学の前川らにより, 厚 生省沉発性血管内血液凝固症調查研究班（この 班名は「症候群」を「症」としている点でおか
しいが,「症候群」の調査研究を班で取り上げる わけには行かないと言う理由でこのようにした のである)で提案され, 最終的に青木, 長谷川2) によって改訂された診断基準で, 極めて広く用 いられている. ただしここの診断基準はいささ か煩雑である上に, DICの原因疾患の存在や, 臨 床症状にも得点が加わっている.DICに原因が存 在するのは当然であって，これに得点を加える こと自体が扔かしい上に, 出血症状や臟器症状 に得点を加えることは，このような例では必ず FDPの増加がみられて,それだけでDICの診断が 可能な得点が得られるため, 診断のみを問題に するのなら不必要と思われる.また, 第V項の診 断のための補助的検查成績, 所見も具体的でな いものが多い，なお，肝硬変症については当初 この診断基準からは除外されていたが, 前川ら はDICが存在しないと思われる肝硬変症ではこの 診断基準により約 3 点の得点が得られることか ら, 肝硬変症の存在する例では全体の得点から 3 点を滅した上でこの診断基準に当てはめること を提案している.

しかし,この診断基準は少なくともDICの重症 度を判定する際には有用であり,DICの治療効果 の判定にもしばしば用いられる.

7）産科・小児科領域の診断基準

前述の厚生省のDIC診断基準は,かなり広く用 
表 6. 日本の厚生省研究班による DIC 診断基準

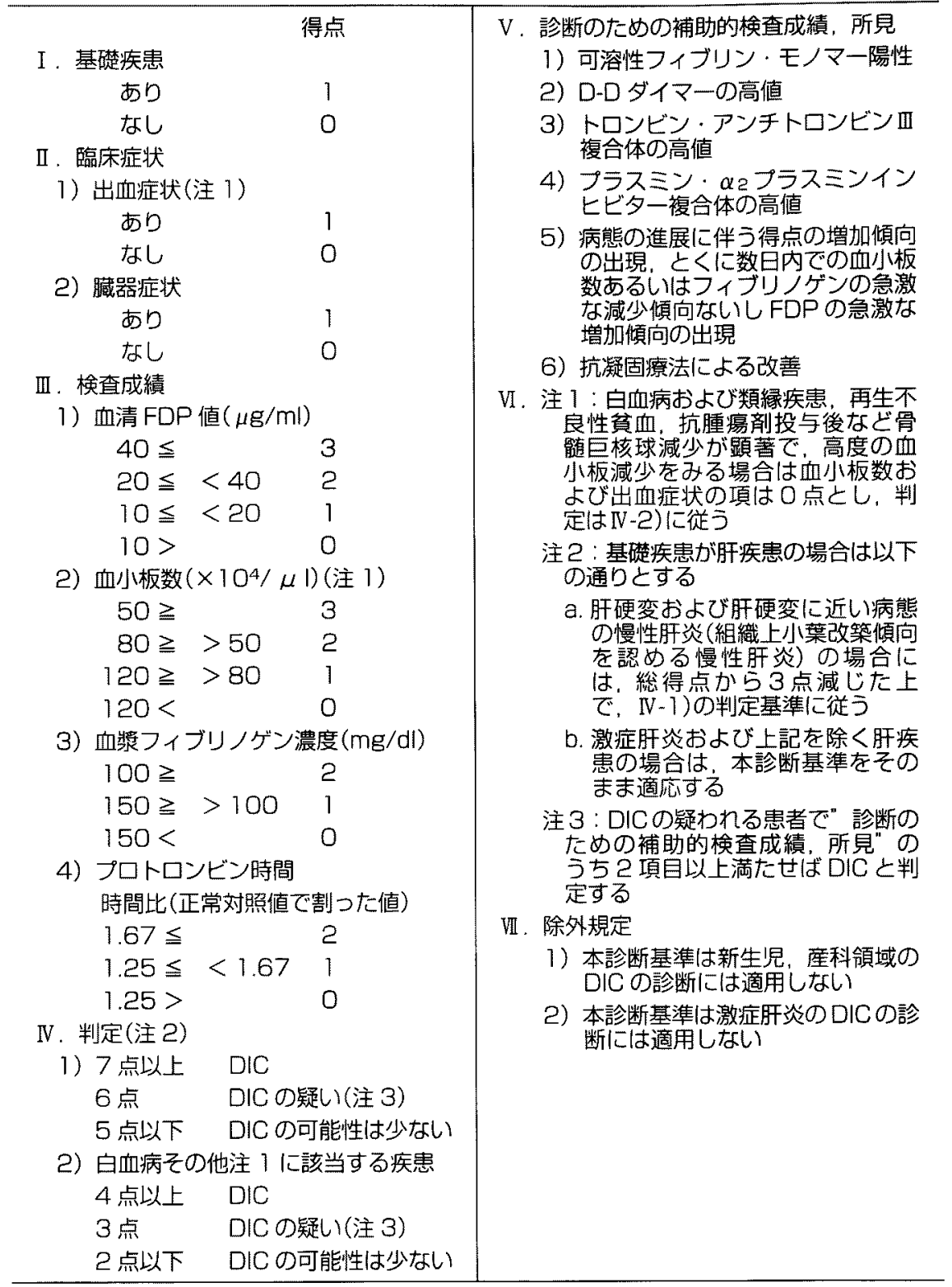

いられているが，必ずしも好評なのではない。 新生児および産科領域のDICの診断には用いない と断っているし，フィブリノゲン産生の増加し ている外科領域では，批判が少なくない．わが 国の産科, 小児科領域では別の診断基準9,10)（表 $7,8 ）$ も提案されているが，ことに産科領域の ものはこのような診断基準が一般の病院でも行
なえるように配虑している。

\section{8）著者 ${ }^{11)}$ の新しいDIC診断基準}

生体内に生じたトロンビンの量を推定する検 查 (前述のTATや, プロトロンビンがトロンビ ンに転化するときにプロトロンビン分子から分 離するペプチドである $\mathrm{F}_{1+2}$ の測定）が普及し， また凝固反応のひきがねとなる組織因子の血中 
表 7. 産科領域における DIC の診断基準

\begin{tabular}{|c|c|c|}
\hline 検植項目 & 基準 & 備考 \\
\hline $\begin{array}{l}\text { ○フィブリノゲン } \\
0 \text { プロトロンビン. 第V因子 } \\
\text { プラスミノゲン } \\
\text { ○ FDP } \\
\text { * SFMC }\end{array}$ & $\begin{array}{l}15 / \mathrm{mm} \text { 時以下 } \\
4 \text { 分以上 } \\
10 \text { 分以上 } \\
r, k, 2 \text { 倍以上. ma50\%以下 } \\
45 \text { 秒以上 } \\
50 \% \text { 以 } \\
10 \text { 万 } / \mathrm{mm}^{3} \text { 以下 } \\
100 \mathrm{mg} / \mathrm{d} 1 \text { 以下 } \\
50 \% \text { 以下 } \\
50 \% \text { 以下 } \\
40 \mu \mathrm{g} / \mathrm{ml} \text { 以上 } \\
\text { 陽性 }\end{array}$ & $\begin{array}{l}\text { 凝塊異常も参考にする } \\
\text { 凝塊異常も参考にする } \\
\text { 他の条件がそるっていれば } \\
10 \sim 15 \text { 方/ } \mathrm{mm}^{3} \text { でもよい } \\
\text { 他の条件がそろっていれば } \\
100 〜 150 \mathrm{mg} / \mathrm{dl} \text { でもよい }\end{array}$ \\
\hline \multicolumn{3}{|c|}{ 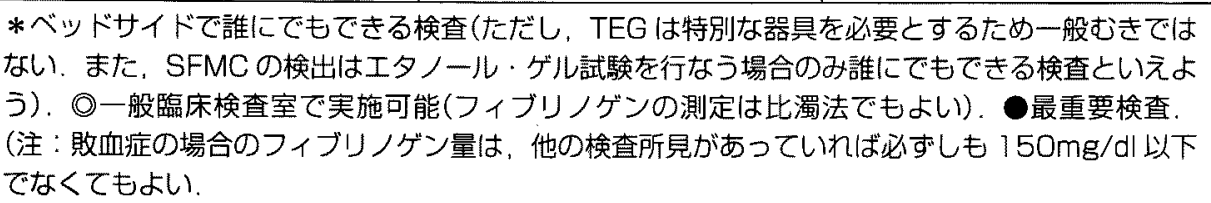 } \\
\hline
\end{tabular}

\section{表 8. 小児科領域における DIC 診断基準}

\begin{tabular}{lc} 
1) 血小板数 $\left(\times 10^{3} / \mu \mathrm{l}\right)$ & Score \\
(a) $150 \sim 100$ & 1 \\
(b) 100 末満 & 2 \\
2) フィブリノゲン $(\mathrm{mg} / 100 \mathrm{ml})$ & \\
(a) $150 \sim 100$ & 1 \\
(b) 100 末満 & 2 \\
3) FDP $(\mu \mathrm{g} / \mathrm{ml})$ & \\
(a) $10 \sim 40$ & 1 \\
(b) 40 より增加 & 2 \\
\hline
\end{tabular}

合計 3 点以上はDIC, $2 〜 3$ 点はDICの疑いとする.

濃度の定量や, 組織因子と活性第VII因子の複合 体の阻此因子 (TFPI, tissue factor pathway inhibitor)の血中濃度の定量が可能となるとともに, DICを診断する新しい基準が得られるかもしれな い. 著者らはこのような可能性に着目し検討を 行ない, 誰でも可能なDIC診断基準を模索したが, 上記の検査は従来のものに代わり得るほどの特 異性はなかった.わずかにDダイマーの測定值が 標準化されればここまでのFDPの定量に代わ り得るのではないかとの結論に達した. その結
果, むしろ現時点ではより簡明な方法がDICの診 断に有用であろうと考え, 1993 年, 表 9 に示す ような診断基準を試案として発表した。

いわゆる厚生省の診断基準 ${ }^{2}$ でDICと考えられ る例では,この試案によりDICと診断できる.問 題はこの試案ではDICと判定されるのに厚生省の 診断基準ではDICと判定されない例である.和田 $ら^{12)}$ はこの試案では厚生省の診断基準で非DIC と診断された例の $25 \%$ 以上も DICと診断される として問題としている.この点については，著 者も最初から心配していた点であり，この新し い診断基集を「試案」として発表したのもこの ためで，今後さらに検討が必要であるが，フィ ブリノゲンやプロトロンビン時間にあまりにも こだわることにより,DICであるのにその早期診 断が遅れる可能性も否定できない.つまり, DIC であることが明白にならないと診断できないよ うな診断基準では治療開始の時期が遅れる可能 性がある。

また，急性前骨䯣球性白血病に合併したDIC のように血小板の産生が低下しているが線溶立 
表 9. 薯者の新しいDIC 診断基準(試案)

(D-dimer の測定值が標準化されれば FDPにかわり得る)

DIC の原因となる疾惠が存在すること

\begin{tabular}{|c|c|c|c|c|}
\hline \multicolumn{2}{|r|}{ 血小板数 } & 10 万 $/ \mu 1$ 末満 & $10 \sim 15$ 万 $/ \mu 1$ & 15 万 $/ \mu 1$ 以上 \\
\hline \multirow[t]{3}{*}{$\mathrm{FDP}$} & $\begin{array}{l}10 \mu \mathrm{g} / \mathrm{ml} \text { 以上 } \\
20 \mu \mathrm{g} / \mathrm{ml} \text { 末満 }\end{array}$ & DIC の疑いが強い & DIC かもしれない & \\
\hline & $\begin{array}{l}20 \mu \mathrm{g} / \mathrm{ml} \text { 以上 } \\
30 \mu \mathrm{g} / \mathrm{ml} \text { 未満 }\end{array}$ & $\mathrm{DIC}$ & DIC の疑いが強い & DIC かもしれない \\
\hline & $30 \mu \mathrm{g} / \mathrm{ml}$ 以上 & $\mathrm{DIC}$ & $\mathrm{DIC}$ & DIC の疑いが強い \\
\hline
\end{tabular}

3〜 5日以内のFDPの著增，血小板の著減はDICの疑いが強い，血小板産生低下のみられる例

ではFDPのみが参考になる，重症感染症で，肝機能異常，血清蛋白低下がないのにフィブリノ

ゲンが正常であればDIC が疑われる. DIC の原因となる疾患が存在することは絶対に必要であ

り，そのような疾患が発見できない場合には DIC と診断しない，

\section{表 10. Taylor 5の DIC 診断基準}

overt DIC の診断基準

1. リスク評価：DICに関連するとされている基檚疾惠一敗血症/重症感染症(なんらかの微生物による)，外傷(多発

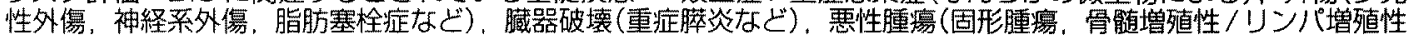
悪性腫瘍)，産科疾患(羊水栓塞，胎盤早期剥離），血管異常(Kasabach-Meritt 症候群。巨大動脈瘤)、重症肝不 全，重症中毒または免疫反応(蛇咬傷，recreational drugs，不適合輸血，移植時拒絶反応）一のあるときに次に 進む。ないときにはこの基準は使用しない。

2. 血小板数、プロトロンビン時間，フィブリノゲン，SFMC またはFDP(フィブリン分解産物)の検查を指示する，

3. 血小板数 $(/ \mu 1):>10$ 万 $=0$ 点, $<10$ 万 $=1$ 点. $<5$ 万 $=2$ 点

フィブリン関連マーカー (SFMC またはFDP)：増加せす＝0 点，中等度増加 $=1$ 点，著明增加 $=3$ 点

プロトロンビン時間延長 : $<3$ 秒 $=0$ 点. $>3$ 秒しかし $<6$ 秒 $=1$ 点, $>6$ 秒 $=2$ 点

フィブリノゲン量 : > 100mg/d l =0点，<100mg/d =1点

4. スコアを計算する。

5. 5 点以上 : overt DIC. 毎日スコアリングする

5 点未満：確定的ではないが non-overt DIC が疑われる. 1 2 日後再評価.

non-overt DIC の診断基準

1.リスク評洒：DICに関連するとされている基礎疾患があるか?

ある $=2$ 点，ない $=0$ 点

2. 主な基準

血小板数 $(/ \mu 1):>10$ 万 $=0$ 点， $<10$ 万 $=1$ 点

+ 增加傾向 $=-1$ 点, 安定傾向 $=0$ 点，低下傾向 $=1$ 点

プロトロンビン時間延長 : $<3$ 秒 $=0$ 点, $>3=1$ 点

+ 短縮傾向 $=-1$ 点. 安定傾向 $=0$ 点，延長傾向 $=1$ 点

$S F M C$ または FDP : 正常 $=0$ 点，增加 $=1$ 点

+ 低下傾向 $=-1$ 点, 安定傾向 $=0$ 点, 增加傾向 $=1$ 点

3. 特異的基準

アンチトロンビン: 正常 $=-1$ 点，低下 $=1$ 点

プテイン $\mathrm{C}:$ 正常 $=-1$ 点，低下 $=1$ 点

TAT : 正常 $=-1$ 点, 增加 $=1$ 点

その他 : 正常 $=-1$ 点, 異常 $=1$ 点

4. スコアを計算する.

進の著明なDIC（著者らはこれを線溶優位型DIC と呼んでいる) と, 重症感染症に合併したDIC のように線溶は兄進していてもそれがさほど著
明ではないDIC（著者らはこれを凝固優位型DIC と呼んでいる）の診断に同じ診断基準を使うこ との可否について，もう少し考えるべきかも知 
表 11. 著者の DIC 治療基準

\begin{tabular}{|c|c|c|c|}
\hline & 薬剛 & 治療の目標 & 用量その他 \\
\hline $\begin{array}{l}\text { DIC の原因 } \\
\text { の除去 }\end{array}$ & & & 最も重要 \\
\hline \multirow{6}{*}{ 抗凝固療法 } & ヘパリンの点滴静注 & \multirow{6}{*}{$\begin{array}{l}\text { FDP } 10 \mu \mathrm{g} / \mathrm{ml} \\
\text { 以下 }\end{array}$} & $\begin{array}{l}\text { 通常 } 5.000 \sim 10,000 \text { 単位/日. TATが低下しないとき } \\
\text { には増量 }\end{array}$ \\
\hline & $\begin{array}{l}\text { 低分子ヘパリンの点滴 } \\
\text { 静注 }\end{array}$ & & 体重 $1 \mathrm{~kg}$ に 75〜 120 単位/日 \\
\hline & 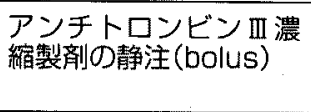 & & 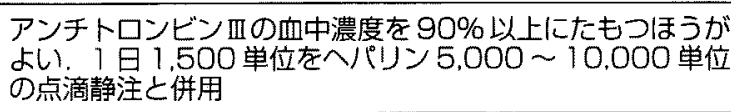 \\
\hline & $\begin{array}{l}\text { メシル酸ガベキサート } \\
\text { の点滴静注 }\end{array}$ & & 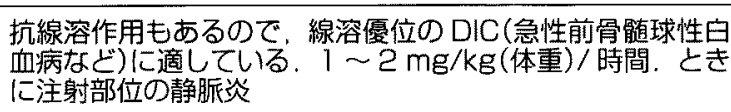 \\
\hline & $\begin{array}{l}\text { メシル酸ナンアフモス } \\
\text { タットの点滴静注 }\end{array}$ & & 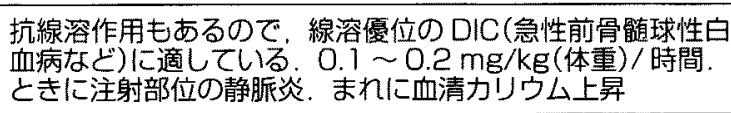 \\
\hline & ヘパリンの皮下注射 & & $\begin{array}{l}\text { 血小板数7万/ } \text { 少以上の慢性DICに適している，5.000単 } \\
\end{array}$ \\
\hline \multirow{3}{*}{ 補充療法 } & 濃厚血小板 & 血小板数 3 万 $/ \mu 1$ & 急性白血病のDIC には必須 \\
\hline & 新鮮凍結血漿 & $\begin{array}{l}\text { フィブリノゲン } \\
\text { 100 mg/d }\end{array}$ & 主として肝障害の著明なDICに \\
\hline & 濃厚赤血球 & $\begin{array}{l}\text { ヘマトクリット值 } \\
\text { 25\% }\end{array}$ & $\begin{array}{l}\text { 急いでへマトクリット值を上昇させないように注意する(急 } \\
\text { 性心荕梗塞様の心電図が発現するこどある) }\end{array}$ \\
\hline
\end{tabular}

れない.たとえば線溶優位型DICでは, 早期より たしかにフィブリノゲン量の低下やプロトロン ビン時間の延長がみられることが多いのに, 凝 固優位型DICではフィブリノゲンの増加が観られ ることもあり, プロトロンビン時間はしばしば 正常だからである.

\section{9） Bick $^{13)}$ のDIC診断基準}

1995 年, アメリカのBickは, その総説のなか で, DICの診断基準を発表している. FPA(フィ ブリノゲンのフィブリン人の転化に際して遊離

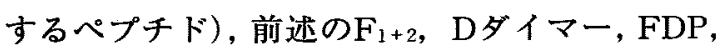
アンチトロンビン,$\alpha_{2}$ プラスミンインヒビター, フィブリノゲン, 血小板, 体温, mean arterial pressure, 脈拍数, 呼吸数, $\mathrm{PaO}_{2}, \mathrm{pH}$, クレア チニン, LDH, アルブミン, $\mathrm{Na}^{+}, \mathrm{K}^{+}$, ヘマト クリット，白血球と言う 20 項目に+4から 4 までの得点を与えるゃり方であるが，あまりに も煩雑な上に，ルーチン検查化していないもの (たとえばFPA) やDICの診断に必要不可欠と思
われない要素まで加わっていて，著者は賛成で きない.

\section{0) TaylorらのDIC診断基準}

前述の 2001 年のSSCではTaylorらは, 表 10 のようなスコアリングによるDIC診断基準を発表 している.この診断基準は, overt DICと non-overt DICとに分かれていて， non-overt DICについて は血小板数,プロトロンビン時間, SFMCまたは FDPのようないわゆる fibrin-related markerが重 要だとしつつも結果を明示せず，世界各国で共 同して今後作成すべきとしている，この点，こ の診断基準は完成したものではない，またこ とにnon-overtDICについては，アンチトロンビ ン，プロテインC,TATなどを重視しているが， これらはプロトロンビン時間同様DICに特異的で ないことは，著者が何度も強調しているところ で賛成できない，なお，この基準は原文では， 血小板数については $10^{9} / l$ を,フィブリノゲン量 についてはg/lを単位として使用している. 


\section{DICの治療基準}

この点については, 明らかな治療基準として はあまり発表されていない.DICの場合, 出来る だけ早期に診断し治療を開始したほうが好結果 が得られる14)のであるが,このことがDICの診断 基準と微妙な関連のあることは先にも述べたと 扔りである．欧米ではこれまでは通常の血栓症 に用いられたのと同程度のへパリン量が使用さ れたが，著者はこれよりはるかに少量で十分で あると考えている.

表 11 は著者 ${ }^{15)}$ の示した治療基準である. 抗凝 固薬の投与はDICの治療にある程度は有効であっ ても，原因除去ができなければその効果は十分 ではない。つまり，抗凝固薬は原因の除去のた めの時を稼ぐのが最も大きな目的と考えられる. その上, 金沢大学朝倉らは急性白血病に合併し たDICの大部分はへパリンのような抗凝固薬の投 与は不要で, 原因疾患の治療, ことに急性前骨 髄球性白血病に合併したDICの多くでは, ATRA の投与と血小板の補充（急性白血病では血小板 数は原因である白血病自体により低下する）の みで十分（白血病細胞の多い例では，へパリン を使用したほうが良い）と考えている。この点 でも診断の場合と同様, 同じDICでも急性白血病 のような血液疾患に合併するものと，重症感染 症に合併するものとはその治療を区別すべきと 考える。

\section{まとめ}

DICの診断および治療基準について紹介した。 DICのover diagosis（誤診と言っても良い）をあ まりおそれると,DICの治療の時期が遅くなるこ とに問題がある，著者は診断にはFDP（または D-ダイマー）とDICを生ずるような原因疾患の 存在が, 治療にはDICの原因の除去が最も重要と 考えている. 従来, DICは急性白血病に合併する
もののように線溶六進の著明なものも，重症感 染症に合併するものも，同一の基準で診断・治 療が行なわれる傾向があったが，今後両者を区 別すべきかも知れない。

\section{文献}

1）松田 保：キリンの血圧はなぜ高い, 初版, 小学館, 東 京, 1999, 148-153.

2）青木延雄，長谷川淳：DIC診断基準の「診断のための補 助的検查成綪，所見」の項の改訂について，厚生省特定 疾患血液凝固異常症調查研究班, 青木延雄班長, 昭和 62 年度業績集報告, 1988, 37-41.

3）松田 保：DICの臨床一播種性血管内凝固の臨床一, 第 1 版, 新興医学出版, 東京, $1997,1$.

4) Colman RW, et al: Disseminated intravascular coagulation. Am J Med 52 : 679-689, 1972.

5) Al-Mondhiry $\mathrm{H}$ : Disseminated intravasucular coagulation; experience in a major cancer center. Thromb Diath Haemorrh 34 : 181-193, 1975.

6）松田 保：血管内凝固症候群(DIC). 臨床血液 $17: 1139$ 1152, 1876.

7) Siegal $T$, et al: Clinical and laboratory aspects of disseminated intravascular coagulation (DIC) ; a study of 118 cases. Thromb Haemostas 39 : 122-134, 1978.

8) Spero JA, et al:Disseminated intravascular coagulation: findings in 346 patients. Thromb Haemostas $43: 28-33$, 1980.

9）真木正博,他：産科領域における急性DICの臨床 95 例か 5. 厚生省特定疾患沉発性血管内血液凝固症調查研究班 小宮正文班長，昭和 54 年度業䄣集報告，1980,18-22.

10）山田兼雄, 他：新生児のDIC治療. 厚生省特定疾患汎発 性血管内血液凝固症調查研究班, 小宮正文班長, 昭和 54 年度業績集報告, 1980, 138-141。

11）松田 保, 他：DICの診断基準の問題点；フィブリノゲ ンとプロトロンビン時間の意義について. 厚生省特定疾 患血液凝固異常症調查研究班, 松田保班長, 平成 5 年度 研究報告書, 1993, 37-41.

12）和田英夫,他：厚生省DIC診断基準を用いたDIC診断にお ける global testの評洒. 血栓止血誌 $12: 197-205,2001$.

13) Bick RI : Disseminated intravascular coagulation; objective criteria for clinical and laboratory diagnosis and assessment of therapeutic response. Clin Appl Thromb/ Hemostas 1: 3-23, 1995.

14) Wada $T$, et al: Outcome of disseminated intravascular coagulation in relation to the score when treatment was began. Thromb Haemostas $74: 848-852,1995$.

15）松田 保：DICの臨床一播種性血管内凝固の臨床一。第 1 版, 新興医学出版, 東京, $1997,106$. 